\title{
SEBERAPA PENRINTINGNYA PENTINGNYA PEMAKAIAN MASKER PADA MASA PANDEMI COVID-19
}

\author{
Rachmad Pandu Abi Echilada Soehartanto \\ Instirut Ilmu Kesehatan Strada Indonesia \\ rachmadpandu17@gmailm.com
}

\begin{abstract}
ABSTRAK
Dimasa sekarang dengan adanya virus covid 19 memakai masker sangar perlu karena dapat meminimalisir kita untuk terjangkit virus covid 19 yang sangat berbahaya. Virus ini dapat menyebabkan infeksi saluran pernafasan atas ringan hingga parah yang dapat menimbulkan kematian oleh karena itu kita sangat dianjurkan mengikut prokes yang dianjurkan pemerintah salah satunya adalah memakai masker agar tidak terjangkit virus tersebut, tetapi banyak masyarakat yang mengabaikan prokes tersebut.
\end{abstract}

\section{LATAR BELAKANG}

Seperti kita ketahui bersama bahwa penularan virus corona dapat melalui droplet atau percikan yang dikeluarkan pada saat kita batuk atau bicara. Penularan terjadi ketika percikan terhirup orang lain yang ada di sekitar. Oleh karenanya, masker dibuat untuk melindungi dari droplet yang di keluarkan oleh orang lain agar tidak masuk ke hidung dan mulut kita ataupun sebaliknya, agar droplet kita tidak mengenai orang lain karena kita tidak tahu kita atau lawan bicara kita yang sedang menjadi pembawa virus. Ada beberapa masker yang dianjurkan pemerintah antara lain:

- Masker kain

- Masker bedah

- Masker N95

Menggunakan masker sangat efektif dalam pencegahan virus corona. Selain itu, cuci tangan juga sama pentingnya dengan memakai masker. Untuk saat ini pemerintah sangat gencar untuk mengkampanyekan pemakaian masker, mulai dari sanksi sosial hingga materi.

Masker juga dikenal dengan alat pelindung diri. Sebagai alat pelindung diri, masker dirancang untuk memberikan perlindungan kepada pemakainya dan bukan sebaliknya 
menjadi sarana transmisi atau penularan karena penggunaan yang salah. Berikut adalah panduan menggunakan masker yang benar:

1. menggunakan masker bedah, pastikan sisi luar adalah yang berwarna hijau dan sisi dalam yang berwarna putih.

2. Pasang tali masker dengan baik. Jika tali masker perlu diikat, ikat bagian atas terlebih dahulu, kemudian bagian bawahnya.

3. Pastikan masker menutupi hidung, mulut, dan dagu dengan sempurna. Pastikan pula bagian yang ada logamnya berada di batang hidung.

4. Lekukkan strip logam mengikuti lekukan hidung hingga tidak ada menyisakan lubang.

5. Hindari menyentuh bagian tengah masker saat menggunakan dan melepas masker.

6. Buang masker ke tempat sampah dan cuci tangan Anda hingga bersih setelah menggunakan masker

\section{Kasus/masalah}

Di Indonesia kegiatan bermasyarakat mulai aktif kembali seperti beberapa perkantoran yang mulai masuk, sekolah yang masuk dengan sistem bergantian dan kegiatan di lingkungan yang sudah mulai ada dengan mematuhi prokes yang ditentukan namun sangat disayangkan banyak juga warga masyarakat yang tidak mematuhi prokes yang telah ditentukan salah satunya memakai masker. Sering kita jumpai banyak masyarakat yang kurang sadar untuk pemakaian masker saat keluar rumah itu peting dan sangat berguna. Bagaimanakah cara menggunakan masker dengan benar?

\section{Tinjauan Pustaka}

Hasil penelitian menunjukkan bahwa pengetahuan masyarakat tentang covid-19 yaitu berupa pencegahan, penularan, dan upaya-upaya penerapan protokol kesehatan khususnya penggunaan masker dan konsekuensi saat tidak menggunakan masker. Sikap masyarakat ada yang bersifat positif dan ada pula yang bersifat negatif. Beberapa diantaranya meyakini namun ada juga yang tidak meyakini keberadaan covid-19. Namun secara umum, dalam penerapannya masyarakat masih belum patuh terhadap kebijakan penggunaan masker padahal masker sudah sangat mudah dijangkau saat ini. Adapun berbagai bentuk komitmen (kebijakan) pemerintah terhadap masyarakat diantaranya yaitu PSBB, pemberian edukasi atau sosialisasi kepada masyarakat yang sering berkumpul, serta pembagian masker secara gratis 


\section{Pembahasan}

Berikut dampak yang ditimbulkan jika tidak memakai masker atau penutup wajah setiap kali kita berada di tempat umum menurut Pusat Pengendalian dan Pencegahan Penyakit Amerika Serikat (CDC).

A. Mudah Terpapar Virus

Salah satu bahaya tidak memakai masker di tempat terbuka adalah terpapar virus. Seperti yang telah disampaikan oleh WHO, Covid-19 bisa menyebar melalui udara.

Apabila seseorang tidak memakai masker saat keluar rumah, maka virus dapat masuk ke dalam tubuh melalui jalur pernapasan.

Banyak studi membuktikan bahwa penutup wajah (masker dan face shield) efektif dalam mencegah penularan virus melalui cairan atau droplet yang keluar saat seseorang batuk, berbicara, atau bersin.

B. Menyebarkan Virus ke Orang Lain

Bahaya lain dari tidak memakai masker adalah menularkan virus ke orang lain. CDC menegaskan masker dapat membantu kita mencegah orang lain terjangkit berbagai penyakit yang bisa ditularkan melalui udara salah satunya Covid-19.

Berdasarkan penelitian, penggunaan masker secara teratur terutama di saat bertemu teman atau saudara di masa pandemi dapat mengurangi penularan virus secara signifikan.

CDC menemukan banyak orang dengan Covid-19 tidak menyadari bahwa mereka membawa virus di tubuhnya.

Sekitar 40 persen orang positif Covid-19 yang tidak menunjukkan gejala (OTG) berpotensi dapat menularkan virus ke orang lain.

Keberadaan OTG sebagai pembawa virus corona semakin tidak terdeteksi oleh publik. Maka dari itu, memakai masker sangat penting dilakukan untuk mengerem laju penyebaran Covid-19.

C. Membawa Virus ke Tubuh

Bahaya lain akibat tidak memakai masker di tempat umum adalah kemungkinan tubuh membawa virus. Beberapa studi menunjukkan bahwa virus corona dapat bertahan hidup di permukaan benda dalam waktu yang cukup lama. 
Dalam aktivitas sehari-hari, seseorang akan memegang benda-benda yang ada di sekitarnya. Kemudian tidak sadar menyentuh wajah dengan tangan yang mungkin saja terkontaminasi virus.

Maka dari itu, memakai masker sangat penting untuk melindungi tubuh dari virus corona yang dapat masuk lewat area wajah.

Meskipun masker bukan alat pencegahan yang sempurna, namun setidaknya dapat membatasi transmisi virus dari tangan ke area wajah terutama hidung dan mulut.

Dengan demikian dengan hal yang tidak terlalu sulit ini masyarakat dapat mengantisipasi penyebaran covid 19 dan dengan secara tidak langsung masyarakat dapat menekan angka penyebaran covid 19

Namun Melindungi anak sehat dengan masker bisa jadi sangat sulit, banyak pendapat yang menganjurkan agar anak-anak dibawah usia 2 tahun tidak memakai jenis masker apa pun karena mereka memiliki saluran udara yang sangat kecil, mereka berpotensi kesulitan bernapas (Esposito, 2020). Khususnya untuk bayi, yang bisa dilakukan adalah menjaga jarak fisik, bersama dengan mencuci tangan dan menghindari menjilati benda, untuk mengurangi risiko infeksi SARS-CoV-2 seperti yang disorot oleh American Academy of Pediatric.

\section{Kesimpulan}

Disini kita dapat menyimpulkan bahwa dengan cara memakai masker dan menerapkan protokol kesehatan yang ditentukan kita dapat menekan angka penularan virus covid 19 di lingkungan masyarakat dan kita dapat mengetahui jika pada saat menggunakan masker tidak boleh sembarangan dan ada panduan-panduan pemakaian masker yang baik dan benar agar kita dapat mencegah virus covid 19 menular ke diri kita.

\section{Daftar pustaka}

Wahyudi, AMK - Perawat RSU Harapan Ibu Purbalingga(2020)

Lestari S. Alam, Andi Suci (2021) FAKTOR YANG MEMPENGARUHI KEPATUHAN MASYARAKAT TERHADAP PENGGUNAAN MASKER DALAM PENCEGAHAN COVID-19 DI KECAMATAN BIRING KANAYA KOTA MAKASSAR TAHUN 2020.

Journal of Health Research, Vol 3 No 2. Oktober 2020 (84 - 95)

Satgas covid 19,CNN Indonesia (7/10/2020) 
Sodik, M. A., Yudhana, A., \& Dwianggimawati, M. S. (2018). Nutritional status and anemia in islamic boarding school adolescent in Kediri City East Java Indonesia. Indonesian Journal of Nutritional Epidemiology and Reproductive, 1(3), 172-176.

Hidajaturrokhmah, N. Y., Nurikasari, M., Retnaningtyas, E., Siwi, R. P. Y., Sari, N., \& Sodik, M. A. (2018). Effectiveness of health education using audio visual with lectures and poster with lectures of changes in behavior selection of snacks. Indian Journal of Physiotherapy and Occupational Therapy-An International Journal, 12(4), 220-224.

Lila, R. N. M., \& Sodik, M. A. (2019). Risk Factors Of Dental Career Events In Pres School Children Ra Al-Hakim Village Damage Subscription Kesamben Blitar District. Journal of Global Research in Public Health, 4(2), 105-112.

Sodik, M. A., \& Maulina, D. (2021). Analysis Of Android-Based Online Message Gateway Towards The Use Of Plastic Bags On PKK Mother. Journal of Global Research in Public Health, 6(1), 31-37.

Sodik, M. A., Dwianggimawati, M. S., Susanto, S. B., VerniciaHumairo, M., \& Bastian, A. (2020). The Herpes Disease Terms Of Personal Hygiene Of Student Senior High School And How To Manage This Cusses. European Journal of Molecular \& Clinical Medicine, 7(5), 969975.

Sodik, M. A. (2014). Sikap Pencegahan Aborsi Ditinjau Dari Pengetahuan Tentang Bahaya Dan Resiko Kesehatan. Strada Jurnal Kesehatan http://publikasi. stikesstrada. ac. id/wpcontent/uploads/2015/02/9-SIKAP-SIKAPPENCEGAHANABORSI. pdf.

Sodik, M. A., \& Nzilibili, S. M. M. (2017). The Role Of Health Promotion And Family Support With Attitude Of Couples Childbearing Age In Following Family Planning Program In Health. Journal of Global Research in Public Health, 2(2), 8289.

Siyoto, S., \& Sodik, M. A. (2015). Dasar metodologi penelitian. Literasi Media Publishing.

Sodik, M. A. (2018). Merokok \& Bahayanya.

Sodik, M. A. (2015). The "Kimcil" Phenomenon: Sexual Knowledge and Safe Sex Behaviour among Adolescents in Kediri. In The 1st Joint International Conference. 